\title{
GLOBAL PANDEMIC, TECHNOLOGY BOOMS AND NEW BUSINESS TRENDS: THE CASE OF JAPAN
}

\author{
Soo Kee Tan ${ }^{1}$
}

The outbreak of COVID-19 has reshaped business environments across the world. Minimal physical contact quickly becoming the standard practice for how everyone interacts, almost everything is going online and touchless. Japan, as one of the most technologically innovative nations in the world, its technology firms and IT industry have enjoyed a prosperous year. The new global business trend and market demand has created new growth opportunities for Japanese firms in reviving the slumping economy. By exploring new business trends and booms in technology sectors, the intent of this study is to examine the impact of COVID-19 on business. The first section includes a discussion on digitalization and global pandemic technology growth, including examples involving the United States and China. The second section is focused on Japan by examining the COVID-19 impact on Japan's economy, business trends and how this situation has benefitted technology players in Japan. Using business performance records in terms of equity gain and revenue growth, the impact of COVID-19 on business across sectors is investigated, with emphasis on Japan's digital business and industry of automation, robotics and sensor technology. It concludes that the impacts of COVID-19 on the ways of doing business will be long lasting, and is expected to continue benefitting digital business and technology sectors.

Keywords: Pandemic, technology, Japan, business trends

\section{INTRODUCTION}

In just a year, COVID-19 has brought about unparalleled change in the way people work and do business. This pandemic has essentially reset commerce-bringing with it significant implications for many of those businesses unable to maintain a pre-COVID-19 model. Millions of people across the globe have suffered due to lockdown measures with so many losing jobs and closing businesses. With daily COVID-19 cases rising to new levels, many countries are facing new waves of COVID-19 infections. Rampant infections forced many governments into a series of drastic lockdown measures that have closed retail shops, hotels, restaurants, schools and offices, leaving tens of thousands jobless. Logistical and industrial activities have been upended, inducing serious threats to many affected sectors and cloud economy recovery. Many countries have undergone substantial economic downturns and face multiple crises that encompass the economic, health, and social spectrums. Globally, policymakers are providing unprecedented support to households, jobless groups, businesses and affected industries. There is great uncertainty concerning this pandemic and nobody is capable of anticipating the future.

\footnotetext{
${ }^{1}$ Senior Lecturer, Department of East Asian Studies, Faculty of Arts and Social Sciences, University of Malaya, Kuala Lumpur, Malaysia. Email: chensk@um.edu.my
} 
Japan, one of the most advanced nations in the world, has also suffered its biggest economic slump since 1980. It has been a bleak year for many of the industries in Japan due to a severe decrease in domestic consumption and a decade of stagnant economic growth. The outbreak of the COVID-19 pandemic in 2020 has worsened economic situations. In the second quarter of 2020, Japan recorded its biggest negative GDP growth at -10.2 percent, with -5.8 percent in the third quarter of $2020 .^{2}$ The service sector, which accounts for more than 60 percent of Japan's GDP, suffered the most as economic activity became significantly constrained. Private consumption declined sharply, particularly in the sectors of tourism, retail, wholesale and the hospitality industry. The economic situation has been further dampened with the outbreak of a third wave of COVID-19 in January 2021. As a result, Japan's services sectors shrank at the fastest pace since September 2020. The latest Purchasing Managers' Index (PMI) as of Feb $3^{\text {rd }} 2021$, which includes both manufacturing and services, reached the lowest level since September 2020. ${ }^{3}$ With a resurgence in infections and a state of emergency, Japan's domestic consumption and output have been dampened further. The uncertainties of the prolonged pandemic have put further pressure on an economy that was already struggling for many years.

While many businesses face the risk of closure or bankruptcy, particularly tourism, the technology industry in Japan has served as a beacon for Japan's economy. COVID-19 has affected many industries, but it has also created new business opportunities for pandemic-related industries. As a technologically advanced country, this new way of living has triggered an acceleration of digital transformation for Japan's community. Digitalization has happened across industries, from online customer service, remote working, supply-chain reinvention, artificial intelligence (AI) and machine learning to improve operations. With the new normal of living, market demands for touchless technology and virtual workspaces have accelerated. Consequently, the technology industry in Japan is experiencing exponential growth. As such, Japanese tech giants-NEC, Fujitec, Fujitsu and Toshiba Tec - have seen significant gains as the world has transitioned almost entirely online for work and learning. The TSE Mothers Index, the Japanese stock market, has yielded almost triple the gains seen in the ChiNext Index since March 19 2020, as investors herded to shares related to biotech, e-commerce, online learning and other "stay at home" themes. Attributed to the new normal, touchless technology, robotics and semiconductors have received the highest world demand in business record. As a leading nation in the field of robotics, touchless technology and the Internet of Things (IoT), Japanese technology firms have benefited greatly from this pandemic. This new global trend has created new opportunities for Japanese firms in reviving the slumping economy. In short, the aim of this study is to investigate the impact of COVID-19 on business trends and the pandemic technology sector.

\section{DIGITALIZATION AND THE GLOBAL PANDEMIC TECHNOLOGY BOOM}

With regard to movement restrictions, people have to depend on technology to communicate and get things done virtually. To avoid the risk of becoming infected, people have been meeting via video conferencing, learning from home and shopping online. As a result, technology firms and online merchants have been enjoying accelerated growth in business. Globally, from Asia Pacific to the West, world technology firms and internet retailers such as Alibaba, Apple Inc., Netflix Inc., Google, Microsoft and Amazon Inc. all continue to hit record highs in share prices and business sales records.

\footnotetext{
${ }^{2}$ Japan GDP Annual Growth Rate, Trading Economics, available at: https://tradingeconomics.com/japan/gdp-growth-annual, accessed on 15 January, 2021.

${ }^{3}$ Japan's Service Sector Slump Deepens as COVID-19 Emergency Hits Businesses, Reuters, 3 February, 2021, available at: https://www.reuters.com/article/us-japan-economy-pmi-idUSKBN2A3021, accessed on 5 February, 2021.
} 
For instance, the U.S. giant internet retailer Amazon Inc., which dominates almost half of the U.S. ecommerce market, enjoyed 38 percent growth in annual revenue for the fiscal year of 2020, an increase from USD 280.5 billion in 2019 to USD 386.1 billion in $2020 .{ }^{4}$ As a result, its share price continues to hit new highs with a historical record of share prices at USD 3,277 on Feb 10 2021, which increased 54 percent compared to the previous year. With the sudden surge of market demand for online shopping amid the pandemic, more than 175,000 additional workers were hired by Amazon between March and April 2020 to handle the order increases. Other U.S. internet retailers have also flourished during the pandemic year. Shopify (SHOP) is up 157 percent and eBay is up 45.90 percent. ${ }^{5}$ According to Digital Commerce 360, U.S. consumers spent USD 861.12 billion online with U.S. e-commerce platforms-an incredible 44 percent increase year-over-year. ${ }^{6}$ That is the highest annual U.S. online shopping growth in at least two decades as shown by Graph 1 below.

\section{Graph 1: Comparison of U.S. E-Commerce Growth Vs Total Retail Sales Growth, 2010-2020}

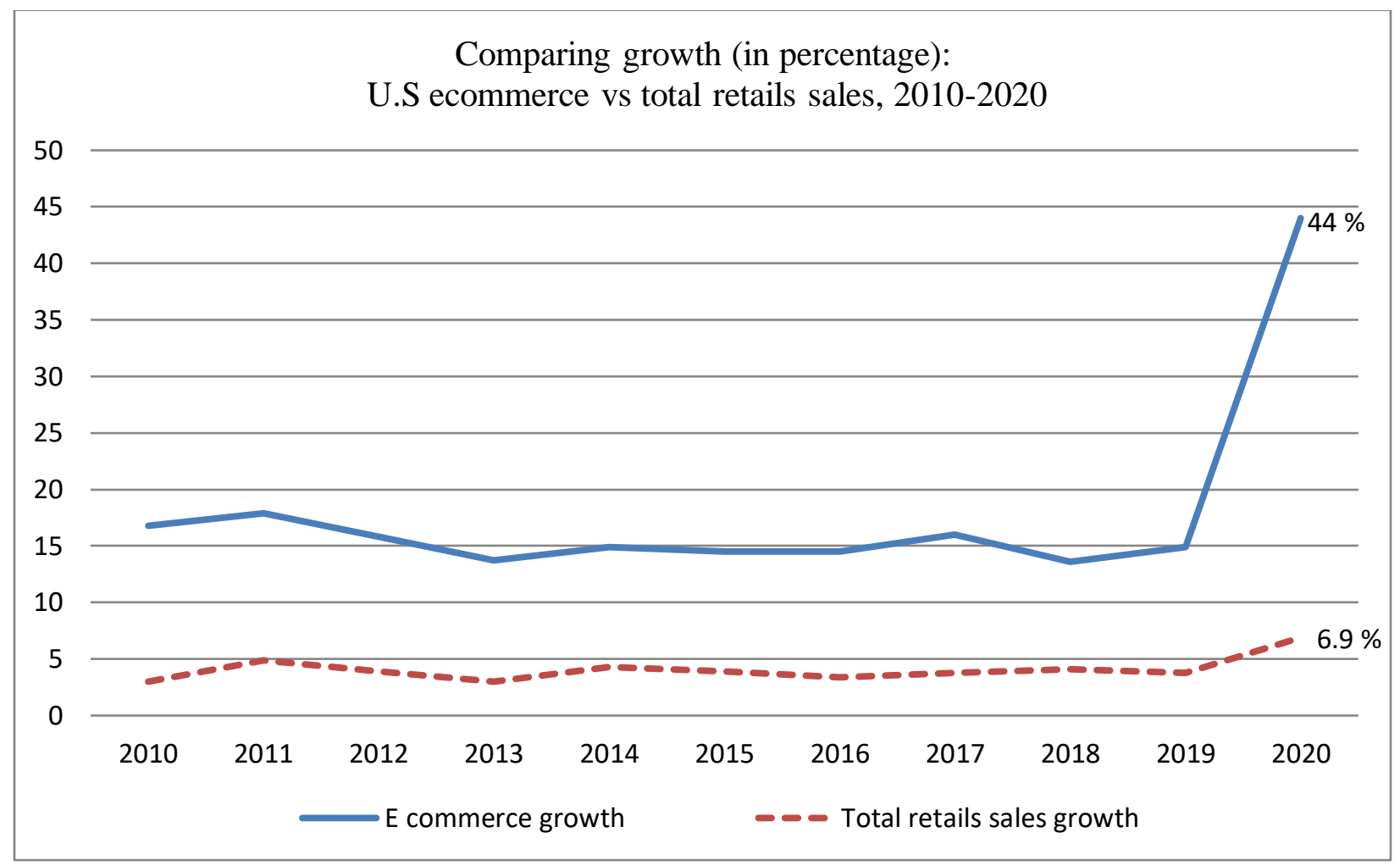

Source: Digital Commerce 360, U.S. Department of Commerce; Updated January 2021.

4 Amazon 2020 Financial Report, available at: https://ir.aboutamazon.com/news-release/news-releasedetails/2021/Amazon.com-Announces-Fourth-Quarter-Results/, accessed on 15 January, 2021.

${ }^{5}$ David John Marotta, “A Market of Stocks Rather Than a Stock Market,” Maratha Wealth Management. October 20, 2020, available at: https://www.marottaonmoney.com/a-market-of-stocks-rather-than-a-stock-market/, accessed on 1 January, 2021. ${ }^{6}$ Fareeha Ali, US Ecommerce Grows $44.0 \%$ in 2020, Digital Commerce 360, 29 January, 2021, available at https://www.digitalcommerce360.com/article/us-ecommerce-sales/, accessed on 1 February, 2021.

${ }^{7}$ Ibid. 
Many investment houses and business leaders predict that the internet retail business and communication technology sector will continue to prosper for a long time on the back of structural demand changes in the market. According to the new McKinsey Global Survey of executives, which conducted a survey of more than 800 business executives globally, 85 percent of respondents in the McKinsey survey said their businesses have significantly digitalized with regard to employee interaction and collaboration, by using video conferencing and file sharing. Roughly half of those surveyed reported increased digitization of customer channels, for example, via video conferencing apps, mobile apps, chat bots and e-commerce. The overall result indicated that the adoption rate of digitization and automation technology has increased by three to four years. ${ }^{8}$ It is expected that most of these changes will be protracted due to changes in work practices. With people adapting to a new praxis of remote working, learn-from-home, meeting and doing business online, many companies and work places will certainly shift to remote working as the accepted paradigm rather than as an option. Therefore, digitalization and changes of consumer behaviors is expected to endure as acknowledged by many business leaders and investment houses as indicated below. Margaret Yang, a strategist with DailyFX in Singapore said that:

"Information technology was no doubt the best-performing sector in 2020, and this trend could carry into 2021 because consumer behavior has been reshaped by COVID-19-related travel bans and lockdown measures. This could have a longlasting impact on consumer behaviors and preferences"9

The outbreak of COVID-19 has become a catalyst for the acceleration of digitalization rather than a temporary phenomenon. With the use of video conferencing, cloud storage and various online platforms, people have realized that work can be done online without face-to-face interaction, and with more efficiency and cost-saving. Certainly, the shifts in the way of living have rewarded companies at the cutting edge of mobility and remote working. With the sudden surge of demands for cloud computing, IoT, computers, robots and anything that is related to touchless technology, sales records of pandemic related sectors achieved remarkable results. It is proven with the latest business performance record of the technology sector. For instance, technology has been the best-performing sector in 2020 in the United States, and its position as the largest sector within the S\&P 500 is shown in the chart below (Graph 2).

\footnotetext{
${ }^{8}$ Mckinsey \& Company, Mckinsey Report, available at https://www.mckinsey.com/featured-insights/future-of-work/what800-executives-envision-for-thepostpandemicworkforce\#: :text=As\%20nonessential\%20workers $\% 20$ shifted $\% 20$ to,such $\% 20$ as $\% 20$ videoconferencing $\% 20$ an d\%20filesharing, accessed on 1 January, 2021.

${ }^{9}$ Kentaro Iwamoto, Sea and BYD biggest winners among major Asia stocks in 2020, Nikkei Asia Review. 28 December, 2020 , available at: https://asia.nikkei.com/Spotlight/Market-Spotlight/Sea-and-BYD-biggest-winners-among-major-Asia-stocks-in$\underline{2020}$, accessed on 1 January, 2021.
} 
Graph 2 Total Equities Return by Sector and Industry in S\&P 500, 2020

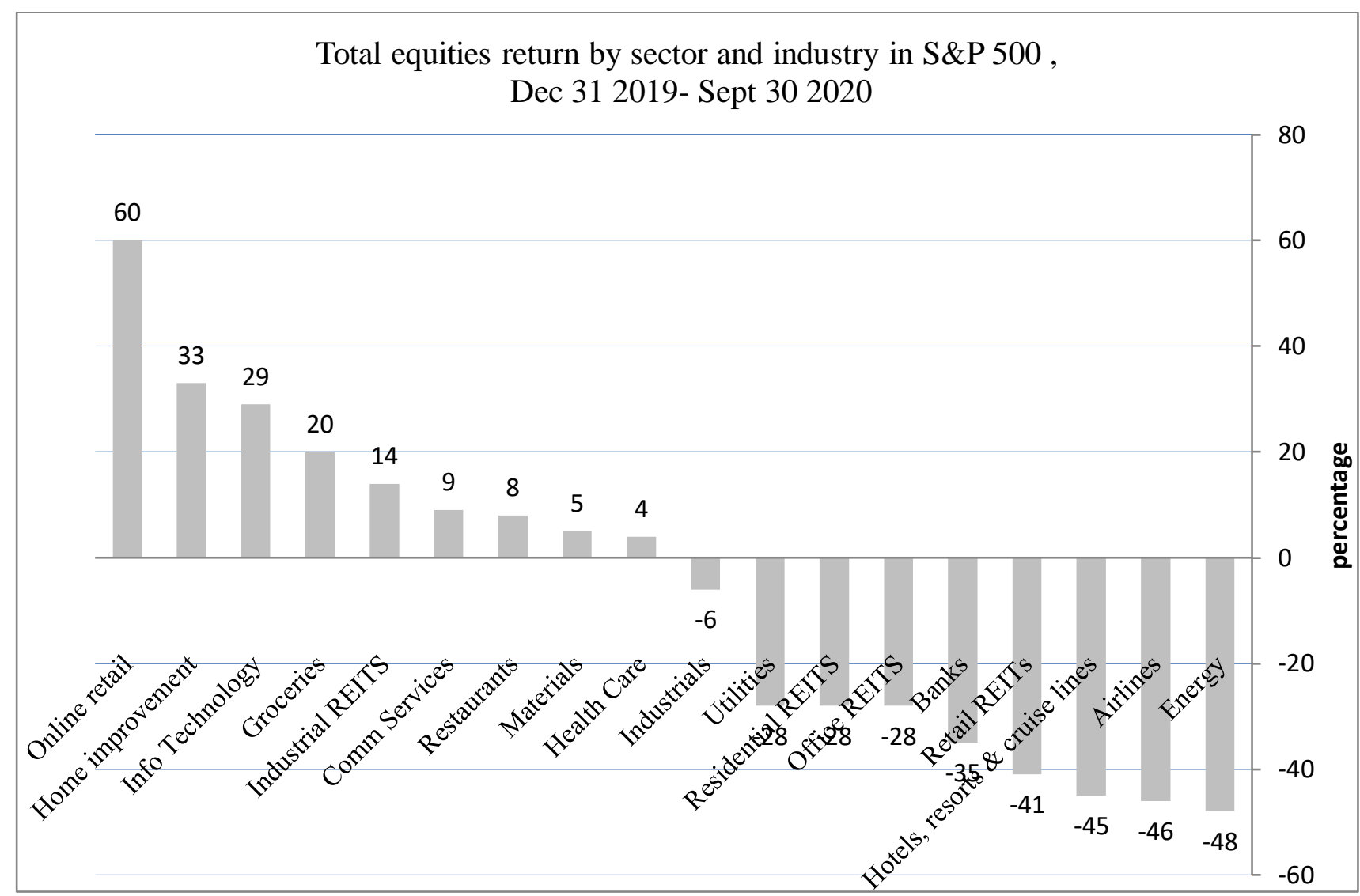

Source: FactSet, Standard \& Poor's, J.P Morgan Asset Management. Guide to the Markets-U.S.

This chart shows the divergence in returns between the various sectors. The impact of COVID19 has been huge, which has caused shocks to many industries, but it has also brought new business growth to pandemic related industries. Based on this chart, online retail and information technology have benefited the most while the industries of energy and tourism have been the most significantly affected. The equities return of online retailers reached 60 percent in the pandemic year while other sectors were struggling to survive. Total equities return of energy and airlines recorded at minus 48 percent and minus 46 percent respectively. Due to travel restrictions and the slump in demand among travelers, airlines suffered a passenger revenue loss of around 314 billion U.S. dollars in 2020, which threatened the survival of many airline companies. Brian Pearce, the chief economist of the International Air Transport Association, describes COVID-19 as the biggest shock to aviation since World War II. ${ }^{10}$ Carriers have seen their revenues fall by around 80 percent, but operation costs remain high.

\footnotetext{
${ }^{10}$ Pandemic Threatens Global Airline Industry with Financial Losses, VOA News, 24 November, 2020., available at: https://www.voanews.com/economy-business/pandemic-threatens-global-airline-industry-financial-losses, accessed on 1 January, 2021.
} 
Consequently, many airlines that have been unable to raise cash, face running out of liquidity, and have consequently had to declare bankruptcy. Since the outbreak of COVID-19, more than 40 airlines worldwide have gone bankrupt or ceased operations by the end of 2020, this included Air Italy, Cityjet, Virgin Australia, Thai Airways, AirAsia Japan, and Cathay Dragon. IATA director general Alexandre de Juniac said that the crisis is lasting longer than anyone could have imagined, especially when the initial support programs of government ran out. ${ }^{11}$ With international traffic levels set to remain limited through 2021, it is expected that the airline industry faces challenges ahead.

As the world became overturned and many businesses were forced to close, the technology sector that supported digitalization flourished. Top-performing tech firms such as Microsoft, Facebook, Instragram, Whtsapp, Google, and Zoom have attained near all-time highs with the surging demand of information technology products. The world's second largest internet company, Alphabet (Google), had its revenue rise 23 percent from last year; especially its cloud business; YouTube had also achieved record sales. For instance, YouTube ads gained a 46 percent jump in 2020 from Q4 2019, a surge in viewers and an increase in the time spent viewing. ${ }^{12}$ Google Cloud's revenue also grew incredibly by 47 percent year-over-year, as more firms and the general public chose to use cloud services. The shift to remote working has boosted the cloud computing business and has benefited all the giant IT companies. Microsoft's cloud business was up 23 percent from last year, with 50 percent growth in Azure. The global cloud computing market has been forecast to rise substantially as digitalization speeds up. In today's globally digital world, almost everything online depends on cloud services, this includes operating systems, databases, web servers, IP addresses, IoT, advanced robotics, drones, AI and blockchains. As market demands for technology services have become incredibly high, the technology sector ranked as the best-performing sector in 2020, and has taken its position as the largest sector within the S\&P 500. Table 1 below shows the list of best performing stocks in the United States (Nasdaq $100)$ in 2020.

Table 1 Top Performing Stocks in The United States (NASDAQ 100), 2020

\begin{tabular}{|l|l|c|}
\hline COMPANY & INDUSTRY & PRICE CHANGE - 2020 \\
\hline Tesla Inc. & Motor Vehicles & $743 \%$ \\
\hline Moderna Inc. & Biotechnology & $434 \%$ \\
\hline Peloton Interactive Inc. Class A & Other Consumer Services & $434 \%$ \\
\hline Zoom Video Communications Inc. Class A & Software & $396 \%$ \\
\hline Pinduoduo Inc. Sponsored ADR Class A & Internet Retail & $370 \%$ \\
\hline DocuSign Inc. & Software & $200 \%$ \\
\hline MercadoLibre Inc. & Internet Software/Services & $193 \%$ \\
\hline Okta Inc. Class A & Software & $120 \%$ \\
\hline Nvidia Corp. & Semiconductors & $122 \%$ \\
\hline PayPal Holdings Inc. & Data Processing Services & $117 \%$ \\
\hline Advanced Micro Devices Inc. & Semiconductors & $100 \%$ \\
\hline Cadence Design Systems Inc. & Software & $97 \%$ \\
\hline Atlassian Corp. PLC Class A & Software & $94 \%$ \\
\hline Idexx Laboratories Inc. & Medical Specialties & $91 \%$ \\
\hline
\end{tabular}

11 ATA Warns of Imminent Airline Bankruptcies, Flight Global, 6 October, 2020, available at: https://www.flightglobal.com/airlines/iata-warns-of-imminent-airline-bankruptcies/140493, accessed on 5 January, 2021.

${ }_{12}$ Alphabet Revenue Up 23\% as Core Advertising Business Shows Strong Growth, CNBC, 2 February, 2021, available at: https://www.cnbc.com/2021/02/02/alphabet-googl-earnings-q4-2020.html, accessed on 5 February, 2021. 


\begin{tabular}{|l|l|c|}
\hline Align Technology Inc. & Medical Specialties & $92 \%$ \\
\hline Apple Inc. & Telecommunications Equipment & $81 \%$ \\
\hline Synopsys Inc. & Software & $86 \%$ \\
\hline Amazon.com Inc. & Internet Retail & $76 \%$ \\
\hline Marvell Technology Group Ltd. & Semiconductors & $79 \%$ \\
\hline T-Mobile US Inc. & Wireless Telecommunications & $72 \%$ \\
\hline
\end{tabular}

Source: Factset ${ }^{13}$

Technology stocks from the software, internet retail, semiconductor and telecommunications industries topped the list of best performing stocks in 2020. Due to COVID-19, everything that supports virtual meetings and remote working has received good business. Telecommunications equipment companies that sell computers, laptops and smart phones achieved the strongest growth in sales in a decade. According to International Data Corp., sales of laptop and desktop computers exceeded 302 million in 2020, a 13 percent increase from the year before and the most since $2014 .{ }^{14}$ Lenovo led the market with a 25 percent share, followed by HP with a 21 percent share, Dell at third with a 17 percent share and Apple at forth in 2020. ${ }^{15}$ IDC vice president Ryan Reith said that,

"We continue to see gaming PCs and monitor sales at all-time highs, and Chromebased devices are expanding beyond education into the consumer market. In retrospect, the pandemic not only fueled PC market demand but also created opportunities that resulted in a market expansion." 16

The boom of PC and mobile phone sales had also caused shortages in chips, which also brought increases in sales for the semiconductor sector. Among touchless technology products, video conferencing apps saw an unprecedented surge in usage amid strict movement restriction orders. For example, Zoom, an unknown video conferencing app for many people before COVID-19, became a vital tool globally to facilitate working and learning from home. Zoom hit the mainstream and became one of the most popular options available. Eric S. Yuan, founder and CEO of Zoom, said that Zoom had reported 169 percent sales growth for three months by the end of April 2020. He predicted the best was yet to come by saying that,

"We will see a fundamental shift in the way that we work, with regular homeworking becoming the new norm in the years to come. Coronavirus has completely changed how people think about where or how you should work. Millennials grew up realizing that they can get the job done without having to go into the office. Give it

\footnotetext{
${ }^{13}$ Philip Van Doorn, These are the Best Performing Nasdaq and S\&P 500 Stocks of 2020, Martket Watch, 2 January, 2021, available at: https://www.marketwatch.com/story/these-are-the-best-performing-nasdaq-and-sp-500-stocks-of-2020-2020-12$\underline{29}$, accessed on 5 January, 2021.

${ }^{14}$ Aaron Pressman, PC Sales Have Surged for At-home Workers and Learners During the Pandemic, Forbes, 12 January, 2021, available at: https://fortune.com/2021/01/11/covid-computer-sales-lenovo-hp-dell-apple/, accessed on 11 January, 2021. ${ }^{15}$ Statista, available at: https://www.statista.com/statistics/263393/global-pc-shipments-since-1st-quarter-2009-by-vendor/, accessed on 10 January, 2021.

${ }^{16}$ Aaron Pressman, PC Sales Have Surged for At-home Workers and Learners During the Pandemic, Forbes, 12 January, 2021, available at: https://fortune.com/2021/01/11/covid-computer-sales-lenovo-hp-dell-apple/, accessed on 11 January, 2021.
} 
maybe 10 years and the millennials become the leaders and then it will become very common. Coronavirus is just a catalyst." (Eric Yuan, 2020) ${ }^{17}$

As Graph 3 presents, Zoom's revenue escalated from 2020 onwards. In the quarter that ended in October, total sales for the video conferencing company amounted to USD777 million, a rise of 367 percent from the same period of the previous year. With an expansion in share price of almost 400 percent, Zoom is now larger than IBM and AMD. As people became more reliant on Zoom's videoconferencing program for educational and business use, the company expects its revenue to continue to rise.

Graph 3 Zoom's Quarterly Revenue (2019 Q1-2021 Q3)

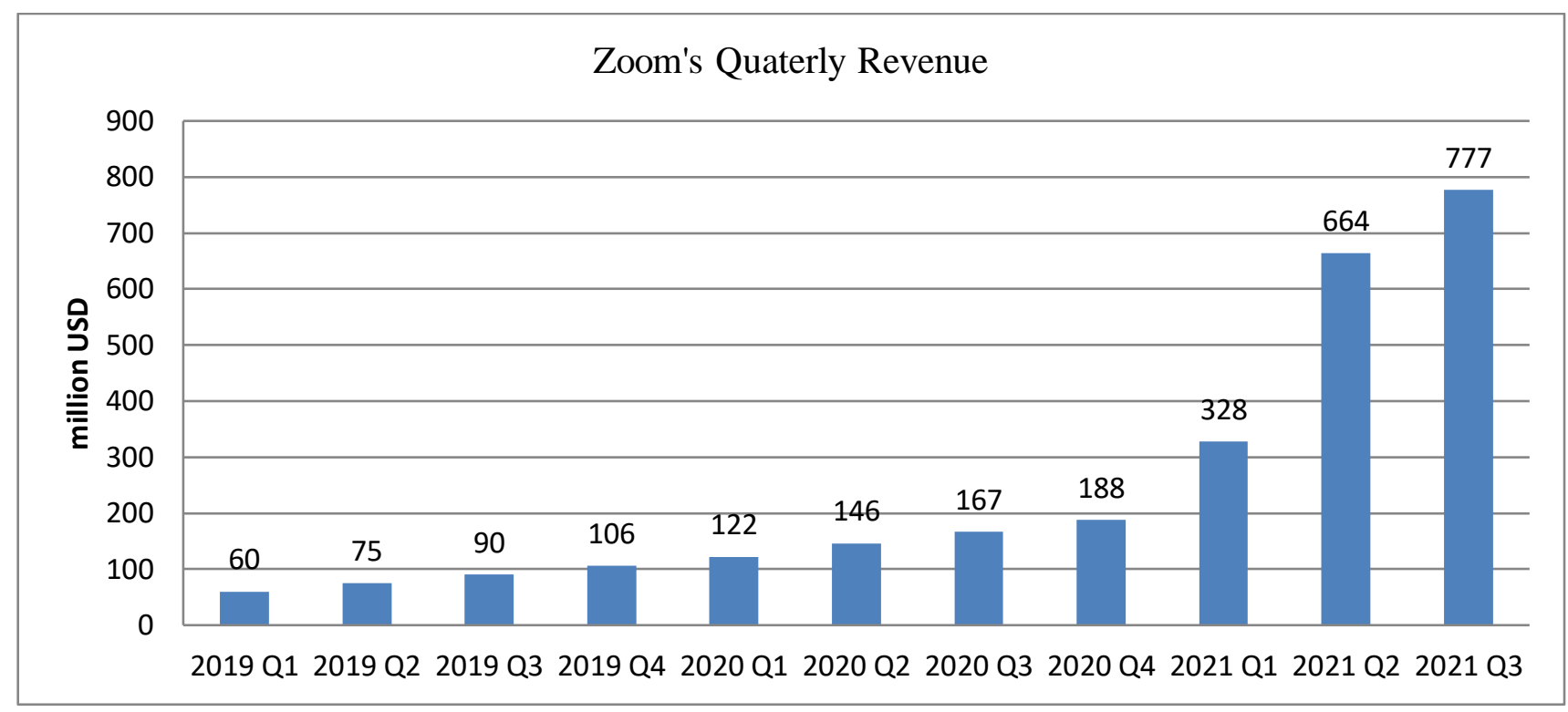

Source: Zoom

In the Asia Pacific, countries such as China, Japan, South Korea and South East Asian countries, similar new business trends have been stimulated by the COVID-19 pandemic. The largest Asian internet retailer, Taobao, operated by Alibaba Group in China, has enjoyed remarkable revenue growth from 1,597 billion yuan in 2015 to 4,361 billion yuan in the fiscal year ending in March 2020, an increase of 35 percent year-over-year (2019-2020). ${ }^{18}$ The increase was mainly driven by the robust revenue growth of commerce retail business and cloud computing in China, particularly since the outbreak of COVID-19 in January 2020. For instance, the sales of Alibaba's digital business have reached over USD 1 trillion (RMB 7,053 billion yuan) in 2020, with increasing demand from cloud computing and digital media, and a total 960 million annual active consumers under the Alibaba online business platform. ${ }^{19}$ Its revenue in cloud computing grew by 50 percent while digital media and entertainment were up 30 percent year-over-year in the December 2020 quarter. ${ }^{20}$ Globally, Alibaba's

\footnotetext{
${ }^{17}$ Emily Cashen, The Zoom Boom, World Finance, 9 February, 2021, available at: https://www.worldfinance.com/specialreports/the-zoom-boom, accessed on 10 February 2021.

${ }_{18}$ Alibaba Group Website, 1 yuan equals approximately 0.14 U.S. dollars and 0.13 euros (as of May 2020).

${ }^{19}$ Alibaba 2020 Financial Report, available at: https://www.alibabagroup.com/cn/ir/presentations/pre200522.pdf

${ }^{20}$ Ibid.
} 
South East Asian e-commerce platform Lazada has also achieved robust growth in business with a recorded quarter of triple-digit year-over-year order growth in $2020 .{ }^{21}$

As technology reshapes shopping habits, more companies are adopting new marketing strategies within the current e-commerce trends. One of the newest directions is livestreaming and a shift from KOL (key opinion leader/influencer) marketing to KOC (key opinion consumer) marketing. By using artificial intelligence and machine learning powered technologies, consumers have discovered the advantages of online shopping platforms and have developed increasing trust in internet shopping platforms in comparison to conventional methods of shopping. Pinduoduo Inc., the largest e-commerce platform for selling agricultural products in China, is another successful example of using KOC marketing and livestreaming to develop business. Pinduduo Inc., founded in 2015, became the second largest internet retailer in China within a few years, and has served as the newest online shopping platform focused on interactive and digital social shopping experiences. One of its core business ideas is its AI-driven Duoduo Farm, the aim of which is to help local farmers to sell online directly to consumers, and consumers could get their desired agricultural products at the best price. The agriculture business of Pinduoduo surged significantly with the outbreak of COVID-19 in January 2020 when the movement of people became restricted. By using livestreaming video, sellers promoted their products on the Pinduoduo app with the help of algorithms, and buyers were able to easily find desirable products through the app. For instance, from February 10 to March 18 2020, Pinduoduo helped 180,000 farmers to sell 120,000 metric tons of agricultural products. According to Pinduoduo, the result was significant enough that, while farmers worried about leftover harvests in the past, the massive demand from Pinduoduo customers generated a stable stream of orders and even cleared the whole seasonal production capacity within days. ${ }^{22}$ With incredible business growth through its innovative AI-driven business model, Pinduoduo has become the most extensive platform of farming products in the world today. Chen, the founder of Pinduoduo said that,

"Pinduoduo uses algorithms to find the product listings with the best cost performance and automatically match them with the consumer's shopping data... To be able to make people buy agricultural products online, you are essentially forcing them to change their buying habit". (Chen, 2020)

Now, the Pinduoduo company is successfully using digital technology to capitalize on surging demands for safe, reliable agricultural products in the wake of the COVID-19 pandemic. Through digitalizing the agricultural supply chain, some of the most serious issues in fragmented agricultural sectors could be addressed, while consumers could get the best fresh food from the farmers directly. Overall, digital business in China is growing at an incredible rate in contrast to other industries. These new business trends have been happening in almost in every corner of the world; South Korea and Japan have also experienced booms in digital business and information technology.

\footnotetext{
${ }^{21}$ Alibaba Highlights for Q4; Live Streaming contributed RMB 400 billion GMV in 2020, China Internet Watch, 2 February, 2021, available at: https://www.chinainternetwatch.com/31097/alibaba-quarterly/;

${ }^{22}$ Chen Du, How Pinduoduo Became Top E-Commerce Company in Just Five Years, According to Its VP, PingWest, 21 December, 2020, available at: https://en.pingwest.com/a/8127, accessed on 11 January, 2021.
} 


\section{THE IMPACT OF COVID-19 ON JAPAN'S BUSINESS TREND AND TECHNOLOGY SECTOR}

Even though it is a world-leading, technologically advanced country, the growth of digital business in Japan has been quite slow compared to other advanced economies. Japan does however, lead in the robotics and automation industries. Pandemic related technologies such as robotics, sensor technology, communication technology and AI are not new in Japanese society. In particular, robotics has seen a surge in demand during the pandemic and has been widely used in the Japanese industrial production and service sectors. With the combination of artificial intelligence and robotics, Japanese robotics is the most competitive in the world, which supplies more than half of the global robotic market. As human contact has been minimized during the pandemic, Japanese robotics and touchless technology have received unprecedented market demand from the world, particularly robots for the healthcare and service sectors. Along with digitalization and teleworking, COVID-19 has served as a turning point for Japanese industries to revitalize the fragile domestic economy.

The COVID-19 crisis has inevitably had a massive impact on Japan's economy. While it slowly recovers with the growth of exports of its technological products, Japan's economy has been hard hit in general due to nationwide movement restrictions. According to Tokyo Shoko Research Ltd, the cumulative number of business failures stemming from the COVID-19 lockdown has reached 1,000 as of Feb 2, 2020. ${ }^{23}$ The restaurant sector, affected by store closures, came as the first, with 182 cases, followed by the apparel industry suffering 91, the construction industry involving 83, and the hotel industry, with $62 .{ }^{24}$ Sluggishness in the restaurant industry also caused business closures of 31 foodmakers and 46 food and beverage wholesalers. Between April and June 2020, Japan suffered its worst post-war quarterly economic contraction with an annualized 29.3 percent in that period recorded overall, minus 4.8 percent for the whole year of $2020 .{ }^{25}$ The economic contraction was mostly attributed to the huge drop in household spending and exports, which accounted for more than 2/3 of Japan's gross domestic product. Takumi Tsunoda, senior economist at Shinkin Central Bank Research, predicts Japanese economic recovery may struggle due to slow vaccine distribution and repeating cycles of infection. ${ }^{26}$ Within the industries, tourism was the worst hit with a declining 97.7 percent of international travelers compared to previous years, due to simultaneous closings of international borders. The airline industry has been hemorrhaging; Air Asia Japan was forced to file for bankruptcy with 21.7 billion yen in liabilities, and has ceased operation effective from October 5 2020, becoming the first airline to close in Japan during the COVID-19 crisis. $^{27}$

While many industries have struggled in Japan, some pandemic related industries have experienced new gains. The COVID-19 impact on Japan's economy has been buffered by its technology sector. Companies involved in communications, AI, robotics, semiconductors and other electronic

\footnotetext{
${ }^{23}$ Pandemic-induced Business Failures in Japan Reach 1,000, Japan Times, 2 February, 2021, available at: https://www.japantimes.co.jp/news/2021/02/02/business/economy-business/1000-business-failures-coronavirus/, accessed on 2 February, 2021.

${ }^{24}$ Ibid.

25 Japan's Economy Shrinks $4.8 \%$ in 2020 due to Covid, BBC News, 15 February, 2021, available at: https://www.bbc.com/news/business-

56066065\#: :text=Japan's\%20economy\%20surged\%20in\%20the,the\%20same\%20period\%20in\%202019, accessed on 18 February, 2021.

${ }^{26}$ Ibid.

${ }^{27}$ Kazuhiro Noguchi, AirAsia Japan Files for Bankruptcy, Leaving 23,000 Flyers Without Refunds, Nikkei Asia, 18 November, 2020, available at: https://asia.nikkei.com/Business/Transportation/AirAsia-Japan-files-for-bankruptcy-leaving23-000-flyers-without-refunds, accessed on 2 February, 2021.
} 
products have seen a surge in business. Based on trade statistics in 2020, Japan's exports of optical, technical, and medical instruments rose by 6.5 percent, and electrical machinery equipment grew by 35.9 percent. ${ }^{28}$ Semiconductor companies in particular, which produce chip manufacturing technology, enjoyed remarkable growth in exports to China that jumped 50.5 percent in January 2021 amid the global shortage in semiconductors. ${ }^{29}$ The rebound of China's economy and subsequently significant demand for chips helped to boost Japan's exports from January 2021, with a 37.5 percent surge to China (see Graph 4). Japan's semiconductor players such as Toshiba and Kioxia are among the winners. With rising demands in autonomous driving, smart cars, AI, automation, 5G and IoT in COVID-19 era, the semiconductor sector remains a core technology in the digital age. The demands for semiconductor chips used for DRAMS, AI and NAND (flash memory) are expected to produce five times more growth than the rest of the semiconductor industry. Japan became a crucial supplier of chips to China after the U.S. ban on Huawei and other Chinese technological firms. For instance, Huawei's purchasing from Japanese suppliers grew by more than 50 percent in 2019 while U.S. trade restrictions on Huawei were tightened. ${ }^{30}$ Jeff Wang, chairman of the Tokyo based subsidiary, Huawei Japan, said that Japan is becoming more important in global supply chains due to the U.S. halt on the export of semiconductor products to many Chinese firms. ${ }^{31}$ With the structural change in demand in the technology market, it is expected that the exporting of high technology products would continue to play a crucial role in supporting Japan's economic growth in a post-pandemic era.

\section{Graph 4 Highlights Japan's Export Growth from Feb 2020-Jan 2021}

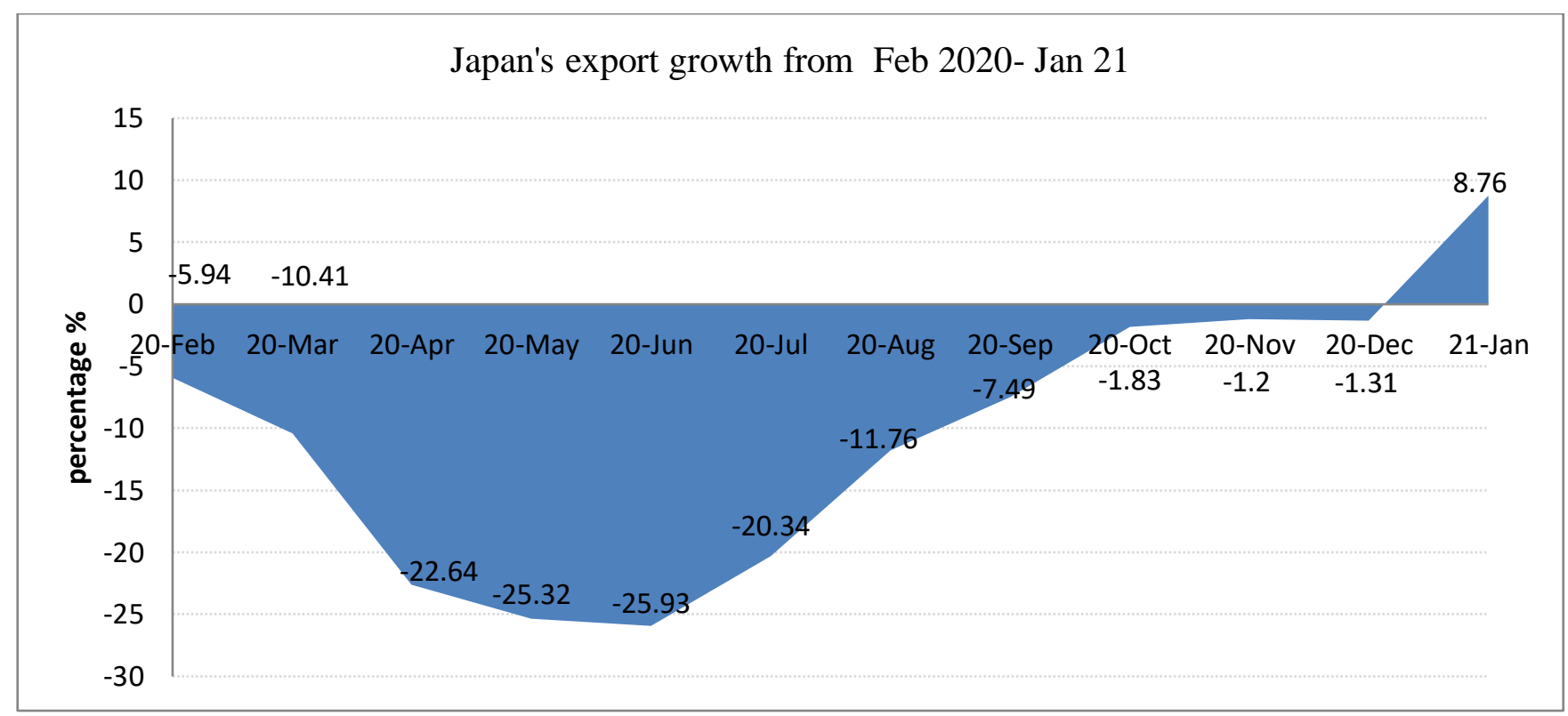

Source: World Top Export

\footnotetext{
${ }^{28}$ Daniel Workman, Japan's Top 10 Exports, World Top Export, available at: http://www.worldstopexports.com/japans-top10-exports/, accessed on 8 February, 2021.

${ }^{29}$ Japan's exports grow at faster pace in January on China demand, Japan Times, 17 February, 2021, available at: https://www.japantimes.co.jp/news/2021/02/17/business/japans-exports-grow/, accessed on 18 February, 2021.

${ }^{30}$ Huawei says Japan 'Extremely Important' After 50\% Rise in Procurement, Nikkei Asia, 27 August, 2020 , available at: https://asia.nikkei.com/Spotlight/Huawei-crackdown/Huawei-says-Japan-extremely-important-after-50-rise-in-procurement, accessed on 8 February, 2021.

${ }^{31}$ Ibid.
} 
With the acceleration of digitalization in the era of COVID-19, Japan's technology sector and digital business are booming. Companies within the software, internet retail, semiconductor and telecommunications industries are among the best performers in the Japanese stock market (see Table 2 and Graph 5). The internet retail industry, led by the Rakuten company, Yahoo Japan and Zozo Town, have seen a sizable increase in online shopping sales records, which has significantly increased the retailer share prices, with yearly performance of 82 percent at industry level (see Graph 5). For example, the largest e-commerce site in Japan is Rakuten, and its share price increased from USD 6.25 on March 92020 to USD 11.57 on May 10 2020, with an 85 percent rise within three months. ${ }^{32}$ The digitalization support industry, such as software companies and the data processing service industry have also experienced share price increases of 79 percent and 65 percent respectively with regard to annual performance. Other industries, such as electrical products, semiconductors and internet software services also rose 58 percent, 55 percent and 49 percent respectively as shown in Graph 5. Overall, the performance of the technology sector in Japan has increased by more than 40 percent as of Feb 2020 to Feb 2021 (see Table 2). In contrast, the energy and airline sectors have suffered the most substantial losses as shown in Graph 5. This trend is similar in other countries.

Table 2 Sector Performance in The Japanese Stock Market (2020-21)

\begin{tabular}{|c|c|}
\hline Sector & Yearly performance $(\%)$ \\
\hline Commercial services & 63.62 \\
\hline Process Industries & 56.67 \\
\hline Technology Services & 45.9 \\
\hline Retail Trade & 42.57 \\
\hline Communications & 42.17 \\
\hline Electronic Technology & 40.81 \\
\hline Health Services & 32.6 \\
\hline Producer Marketing & 29.89 \\
\hline Consumer Durables & 21.05 \\
\hline Consumer Services & 11.27 \\
\hline Distribution Services & 9.72 \\
\hline Health Technology & 7.74 \\
\hline Non-Energy Minerals & 6.93 \\
\hline Utilities & 3.72 \\
\hline Transportation & 3.55 \\
\hline Consumer Non-Durables & 2 \\
\hline Finance & -1.79 \\
\hline Industrial Services & -2.3 \\
\hline Energy Minerals & -10.77 \\
\hline
\end{tabular}

Source: Trading view (annual performance data dated from Feb 20, 2020-Feb 19, 2021)

\footnotetext{
${ }^{32}$ Yahoo Finance, available at: https://finance.yahoo.com/, accessed on 19 February, 2021.
} 


\section{Graph 5 Industry Performance in The Japanese Stock Market (2020-21)}

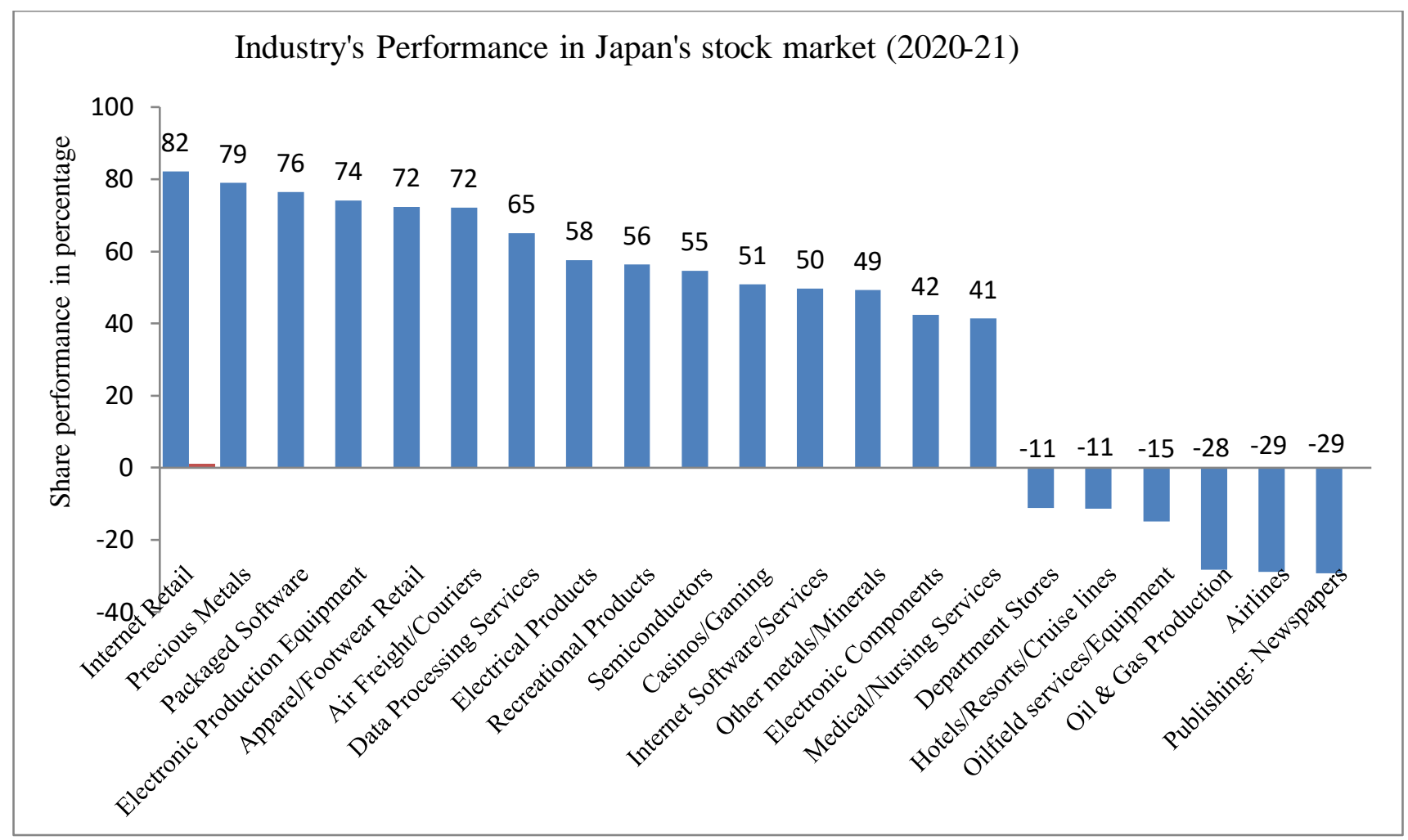

Source: Tradingview (annual performance data dated from Feb 20, 2020-Feb 19 2021)

With rising expectations of a rebound in business growth, the Nikkei index hit the psychologically crucial 30,000 level for the first time since August 1990 on Feb 15 2021. As indicated in Table 2, the best performance sector is in commercial services, followed by process industries, technology services, retail trade, communications and electronics technology. The top-performing stocks in Japan in 2020 included M3 Inc. (+137 percent), which provide online health services, virtual drugmarketing platforms and telemedicine. The video game company Nexon Co, experienced share price increases of 38 percent with the rising demand for videogames among people who have been staying at home. Mercari Inc., a virtual flea-market operator, has had share prices go up 129 percent (see Table 3). Growth in e-commerce has benefited a broad spectrum of Japanese digital business players, such as 
online payments firm Base Inc. (+734 percent) ${ }^{33}$, Softbank affiliate Z Holding Corp (+35 percent) and food delivery website operator Demae-Can-Do (+179 percent). ${ }^{34}$

Table 3 Jumps in Share Prices of Online Business Players in Japan

\begin{tabular}{|l|c|c|c|c|}
\hline Company & $\begin{array}{c}\text { Share price in } \\
\text { pre-Covid } \\
(21 \text { Feb 2020) }\end{array}$ & $\begin{array}{c}\text { Share price } \\
\text { after Covid } \\
(20 \text { Oct 2020) }\end{array}$ & Price changes & Industry \\
\hline Base Inc ${ }^{35}$ & $1697 \mathrm{JPY}$ & $14160 \mathrm{JPY}$ & $+734 \%$ & Software apps \\
\hline M3 Inc & $3055 \mathrm{JPY}$ & $7240 \mathrm{JPY}$ & $+137 \%$ & Online healthcare service \\
\hline SuRaLa Net Co., Ltd & 1208JPY & $8970 \mathrm{JPY}$ & $+643 \%$ & Online learning tool \\
\hline Mercari Inc & $2448 \mathrm{JPY}$ & $5610 \mathrm{JPY}$ & $+129 \%$ & Internet retailer \\
\hline Nexon Co & $1840 \mathrm{JPY}$ & $2546 \mathrm{JPY}$ & $+38.37 \%$ & Video Game \\
\hline
\end{tabular}

Source: Bloomberg

Among the online business players, the achievement of Base Inc. has been remarkable since the outbreak of the pandemic. Established in 2012, Base Inc. has become the market leader in online shop formation in Japan in less than a decade. By providing an online shop solution catering to individuals and small and medium sized businesses in Japan, Base Inc. has attracted many customers who aim to open an online store. Currently, it has reached a cumulative total of over 1.3 million shops on its cloud platform, and due to the pandemic, it has seen a surge in demand for online business. As of December 31 2020, Base's annual net sales achieved a growth of 121.9 percent. Particularly because of the impact of COVID-19, the company enjoyed a huge jump in revenue from March 2020 to May 2020, with a GMV $^{37}$ growth rate of 235 percent. ${ }^{38}$ Since the Japanese government has asked citizens to practice selfisolation and stay at home amid the pandemic, online retail and virtual services have emerged as a popular alternative, which has created a significant increase in the growth of digital commerce.

\section{JAPANESE AUTOMATION, ROBOTICS AND SENSOR TECHNOLOGY DURING THE PANDEMIC}

With lockdown measures and remote working practices, Japan's pandemic related technology firms enjoyed a fruitful year. From the areas of robotics, AI, IT, software, sensors and computer hardware, Japan's technology sector recognized the outbreak of COVID-19 as a crucial turning point for business. With COVID-19, Japanese automation and sensor technology have become more significant as hygiene

\footnotetext{
33 See Table 3.

34 Winners and Losers in Japan's 2020 stock market, The Star, 30 December, 2020, available at: https://www.thestar.com.my/business/business-news/2020/12/31/winners-and-losers-in-japans-2020-stock-market. accessed on 5 January, 2021.

${ }^{35}$ BASE, Inc. engages in planning, development, and operation of web services in Japan. It operates through three segments: BASE Business, PAY Business, and Other Business. The company offers an online shop opening service and a smartphone shopping app under the BASE name; and also provides PAY.JP, an online payment service for ecommerce.

${ }^{36} \mathrm{SuRaLa}$ Net Co., Ltd. offers commercial services throughout Japan. The Company provides electronic learning education consulting, management, marketing promotion, website operation, and other services.

${ }^{37} \mathrm{GMV}$ is the order amount based on the order date.

${ }^{38}$ Base Inc., Q3 Financial Results Briefing for the Fiscal Year Ending December 2020, 13 November, 2020, available at: https://contents.xjstorage.jp/xcontents/AS08546/edb55ac2/24e1/4b1e/b55c/a1556dccee10/20201114132918424s.pdf, accessed on 5 January, 2021.
} 
concerns drive demand for touchless technology. It has been given a new impetus with surging demands under the new normal, with widening applications in manufacturing sites, the service and retail sectors such as in hotels, hospitals, schools, shopping malls, restaurants and any place which incurs human contact. Even before the pandemic, Japan recognized the need to bolster its robotics and sensor technology as labor forces had been shrinking in the country. In fact, Japan's decades of progress in automation, use of robotics and touchless technology have created a solid foundation in its technology industry. Automation was heavily introduced into industrial production and construction work decades ago, with the use of robots are now commonplace in Japanese industries and society. Firms such as Kawasaki Heavy Industries, FANUC and Sony led the way in robotic development during Japan's economic rise in the past. As an example, in 1995, about 700 thousand industrial robots were used worldwide -500 thousand of them were used in Japan. ${ }^{39}$

As the world-leading nation for robotics, Japan currently supplies more than half of the global robot market. Based on Graph 6, Japan's export of robots increased 35 percent from 2010 (407.64 billion yen) to 2019 (549.29 billion yen). Asia is the largest market for Japanese industrial robots; China is the largest importer and it has made rapid developments in robotics in recent years. Market demand for non-industrial robots has increased substantially, such as customer service robots, personal assistant robots, autonomous vehicles and unmanned aerial vehicles (UAVs). With the COVID-19 pandemic, social distancing measures and minimal human contact have boosted market demand for robots. Manufacturers and service providers are forced to rethink manufacturing systems and working methods under remote working and stay at home enforcement measures. As a result, manufacturers have also been forced to look for AI and robotic assistance. For instance, at Toyota, in combination with other AI technology, robots have been used for quality-control inspections, as COVID-19 has accelerated a shift from Toyota's vaunted "go and see" system. ${ }^{40}$ With recent breakthroughs in AI technology with teaching machines how to identify defects, the accuracy of quality control work done by robots has improved substantially. Ran Poliakine, founder of MusashiAI, which sells visual inspection robots said that,

"Inquiries from automakers, parts supplies and other firms in Japan, India, the United States and Europe have quadruples since March 2020... COVID-19 has accelerated the move where working from home is showing that remote work can work." (Poliakine)

Visual inspection robots by Poliakine's MusashiAI, claimed to be the first in the field, can spot defects with the same accuracy and speed as the human eye. The breakthrough of technology in response to and in conjunction with the outbreak of COVID-19 has spurred the increased use of robots as has been evident in market trends.

\footnotetext{
${ }^{39}$ Todd Schneider, Gee Hee Hong, and Anh Van Le, "Land of the Rising Robots," Finance \& Development, Vol. 55, no. 2, June, 2018, available at: https://www.imf.org/external/pubs/ft/fandd/2018/06/japan-labor-force-artificial-intelligence-androbots/schneider.htm, accessed on 8 January, 2021.

${ }^{40}$ Japan Looks to AI as Coronavirus Challenges Quality Control Mantra, Japan Times, 5 September, 2020, available at: https://www.japantimes.co.jp/news/2020/09/05/national/science-health/artificial-intelligence-coronavirus/, accessed on 11 January, 2021.
} 


\section{Graph 6 Value of Manipulators and Robots Exported from Japan (2010-2019)}

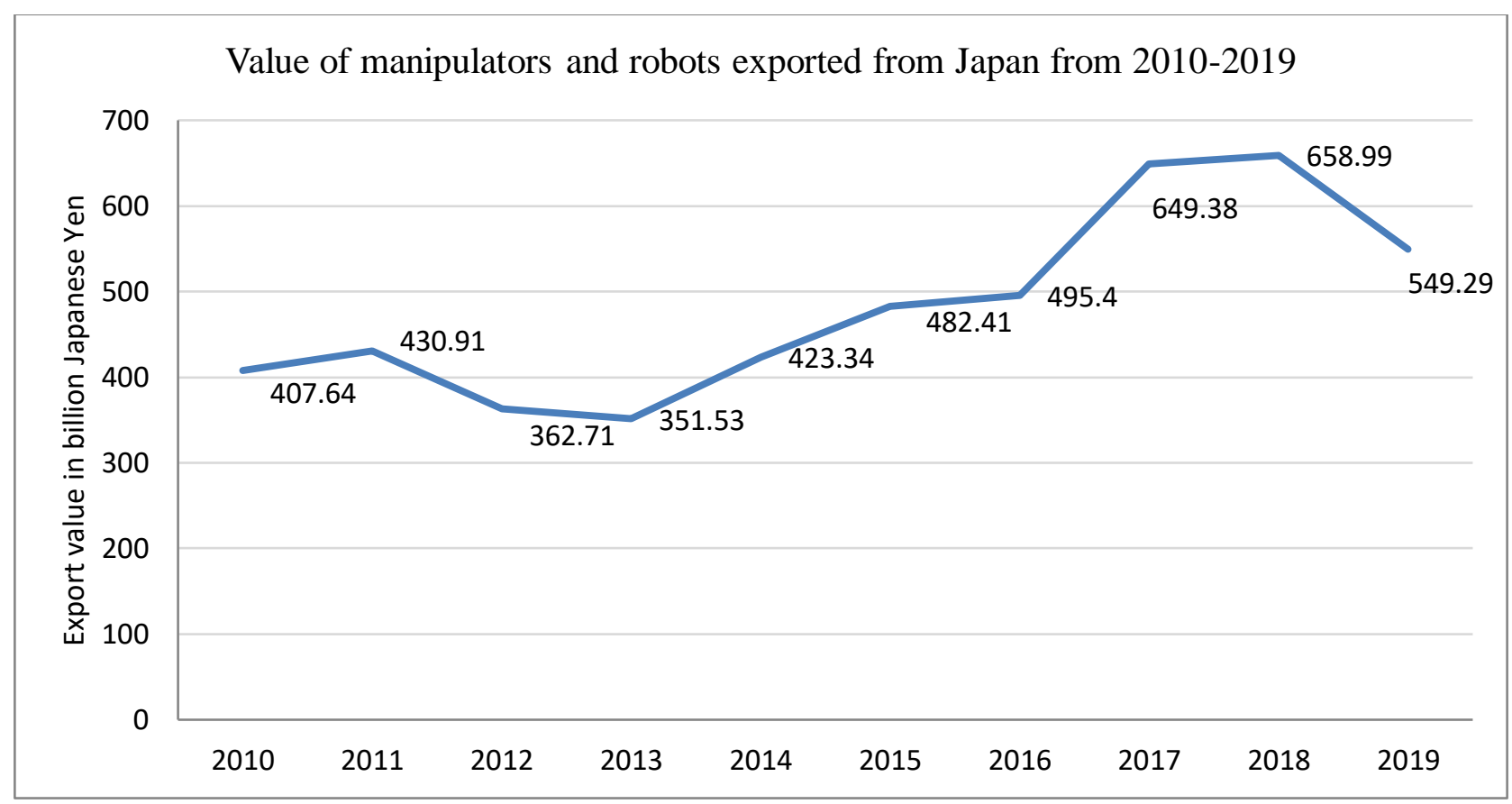

Source: Statista 2021

As the market demands for robots have been increasing, the average robot density in the manufacturing industry hit a new global record of 113 units per 10,000 employees. The world's top 5 most automated countries are: Singapore (1), South Korea (2), Japan (3), Germany (4) and Sweden (5) ${ }^{41}$. The electronics industry in Singapore, especially semiconductors and computer peripherals, is the primary customer of industrial robots, with shares of $75 \%$ of the total operational stock. Despite Japan being ranked third in robot density, Japan is the world leader in robot manufacturing-even robots assemble robots: $47 \%$ of the global robot production is made in Japan. China has recently begun generating the largest market for this technology through acquiring Japanese robotics and has thereby exhibited considerable expansion in the density of robots nationally. ${ }^{42}$

The Japanese sensor technology industry has also benefited from the COVID-19 pandemic. Currently Japanese firms own almost 50 percent share of the global market. ${ }^{43}$ The leading Japanese firms in this industry are NEC, Fujitec, Fujitsu, Japan Inc., Optex and Toshiba Tec. The sensor industry had already benefitted, not only from the boom in smart phone technology, but also from the developments in IoT. With the outbreak of COVID-19, the development of new technologies in targeting pandemic-centered business has been reported at Japanese firms. For instance, lift manufacturer Fujitec has launched a model on May 2020 with an optional add-on touchless panel feature that uses infrared sensors to choose a destination floor based on hand position over a

\footnotetext{
${ }^{41}$ Robot density is the number of operational industrial robots relative to the number of workers

42 World Robotics Statistics, International Federation of Robotics (IFR), available at: https://ifr.org/ifr-pressreleases/news/robot-race-the-worlds-top-10-automated-co.untries, accessed on 2 February, 2021.

43 Touchless Sensor Technology Takes Off in Japan, $A V$ Magazine, 15 April, 2020, available at: https://www.avinteractive.com/news/covid-19/touchless-sensor-technology-takes-off-in-japan-15-04-2020/, accessed on 4 January, 2021.
} 
dashboard. ${ }^{44}$ Contactless elevator control panels became a popular product amid the pandemic to avoid cross-infection, as elevators, especially the buttons, have the potential to create high-risk infection. In addition to touchless lift buttons, Fujitec also developed ionized air purified ventilation systems to improve air quality, so that passengers would not become easily infected. Tested by the Kitasato Research Center of Environmental Science, Fujitec claims that the system can remove 95.5 percent of influenza viruses. ${ }^{45}$ As reported by Fujitec, the model has received an increasing number of orders from hospitals, pharmaceutical manufacturers, food companies and general offices as a hygiene solution in facing the pandemic risks.

NEC, another technology company which has benefited from this pandemic, developed a new facial recognition system which targets pandemic demands. As wearing masks in public and the workplace has become a norm, Japan's NEC Corporation has invented a facial recognition system which identifies faces while wearing masks and sunglasses. ${ }^{46}$ According to NEC, the verification takes less than a second with an accuracy rate of more than 99.9 percent. ${ }^{47}$ The system hones in on uncovered features, such as eyes and other uncovered parts, to verify the subject's identity. The system can be used at security gates in office buildings, hotels, apartments, airports and other facilities. Shinya Takashima, assistant manager of NEC's digital platform division said that,

"Needs grew even more due to the coronavirus...our customers include Lufthansa and Swiss International Airline as touchless verification has become more important due to the impact of COVID-19. Facial recognition means not having to produce a security card, which can be lost or stolen, and also helps prevent the spread of germs from touching surfaces." (Takashima).

According to a report from the National Institute of Standards and Technology, the facialrecognition algorithms failed to identify 20-50 percent of images of people wearing masks before COVID-19. But now it reported a vast improvement in accuracy. ${ }^{48}$ This latest facial recognition system by Fujitec should certainly have a good response from the market amid the pandemic. Attributed to the new normal, touchless technology and robotics have garnered the highest demand recorded in the world as shown in the above discussion.

\section{CONCLUSION}

Globally, COVID-19 has disrupted movement and world trade. The economic damage has been huge and represents the largest economic shock to many countries and industries in decades. Despite the extraordinary efforts of policy makers to supplement economies with fiscal and monetary policy support, the world cannot escape from its deepest recession to date. Japan, which had already slipped into a recession earlier this year, has suffered its biggest economic slump since 1980. It has been a bleak year for many businesses in Japan due to the severe decrease in domestic consumption. However, pandemic

\footnotetext{
44 Ibid.

${ }^{45}$ Fujitec, Company News on 31 December 2020, available at: http://fujitec-hk.com.hk/en/news/202012003, accessed on 7 January, 2021.

46 Masks No Obstacle for New NEC Facial Recognition System, Reuters, 7 January 2021, available at: https://www.reuters.com/article/us-health-coronavirus-japan-facial-recog-idUSKBN29C0JZ, accessed on 10 January, 2021.

${ }^{47}$ Fujitec, Company News on 31 December 2020, available at: http://fujitec-hk.com.hk/en/news/202012003, accessed on 15 January, 2021.

48 Facial Recognition Identifies People Wearing Masks, $B B C, \quad 7$ January, 2021, available at: https://www.bbc.com/news/technology-55573802, accessed on 10 January 2021.
} 
related sectors are booming due to new market pulls. As social distancing and remote working become the norm, software and hardware companies everywhere are benefiting from providing touchless technology and virtual meeting spaces. The tech giants and digital business players in Japan such as Fujitec, NEC, Base Inc. and M3 Inc. have seen significant gains as the world has gone almost entirely online for work and learning. Despite the sluggishness of the economy, the stock market in Japan hit new highs, as investors herded to shares related to biotech, e-commerce, online learning and other "stay at home" areas.

The COVID-19 pandemic has changed the world, and will have far-reaching influences. Digital adoption has taken a quantum leap in many areas, as people still need to carry on with life during the pandemic. With the measures of lockdowns and movement restrictions, COVID-19 has become the catalyst to speed up the use of digital and internet technologies. Many businesses have been forced to change their models in order to survive and stay competitive. With the changes in consumer behavior and the way people work after the first year of the pandemic, the world will never return to a preCOVID-19 lifestyle. The lives of people have been impacted in unparalleled ways and have been substantially changed. During the pandemic, it has been proven that technology is needed to enable business operations and ensure social connectivity remains in place. The outbreak of COVID-19 served as a push factor to advance technology for market needs. As a leading nation in the field of robotics, touchless technology and the Internet of Things, it is expected that Japanese technology firms would continue to benefit greatly from this pandemic. This boom for digital business players and technology firms is not a temporary phenomenon, but has only just begun.

\section{REFERENCES}

Aaron Pressman, PC Sales Have Surged for At-home Workers and Learners During the Pandemic, Forbes, 12 January, 2021, available at: https://fortune.com/2021/01/11/covid-computer-sales-lenovo-hpdell-apple/, accessed on 11 January, 2021.

Alibaba $2020 \quad$ Financial Report, available at: https://www.alibabagroup.com/cn/ir/presentations/pre200522.pdf, accessed on 20 January 2021

Alibaba Highlights for Q4; Live Streaming contributed RMB 400 billion GMV in 2020, China Internet Watch, 2 February, 2021, available at: https://www.chinainternetwatch.com/31097/alibaba-quarterly/; accessed on 20 January 2021

Alphabet Revenue Up 23\% as Core Advertising Business Shows Strong Growth, CNBC, 2 February, 2021, available at: https://www.cnbc.com/2021/02/02/alphabet-googl-earnings-q4-2020.html, accessed on 5 February, 2021.

Amazon 2020 Financial Report, available at: https://ir.aboutamazon.com/news-release/news-releasedetails/2021/Amazon.com-Announces-Fourth-Quarter-Results/, accessed on 15 January, 2021.

ATA Warns of Imminent Airline Bankruptcies, Flight Global, 6 October, 2020, available at: https://www.flightglobal.com/airlines/iata-warns-of-imminent-airline-bankruptcies/140493, accessed on 5 January, 2021. 
Chen Du, How Pinduoduo Became Top E-Commerce Company in Just Five Years, According to Its VP, PingWest, 21 December, 2020, available at: https://en.pingwest.com/a/8127, accessed on 11 January, 2021

Daniel Workman, Japan's Top 10 Exports, World Top Export, available at: http://www.worldstopexports.com/japans-top-10-exports/, accessed on 8 February, 2021.

David John Marotta, “A Market of Stocks Rather Than a Stock Market," Maratha Wealth Management. October 20, 2020, available at: https://www.marottaonmoney.com/a-market-of-stocks-rather-than-astock-market/, accessed on 1 January, 2021.

Emily Cashen, The Zoom Boom, World Finance, 9 February, 2021, available at: https://www.worldfinance.com/special-reports/the-zoom-boom, accessed on 10 February 2021.

Facial Recognition Identifies People Wearing Masks, $B B C, 7$ January, ,2021, available at: https://www.bbc.com/news/technology-55573802.

Fareeha Ali, US Ecommerce Grows 44.0\% in 2020, Digital Commerce 360, 29 January, 2021, available at https://www.digitalcommerce360.com/article/us-ecommerce-sales/, accessed on 1 February, 2021.

Fujitec, Company News, 31 December, 2020, available at: http://fujitec-hk.com.hk/en/news/202012003, accessed on 7 January, 2021.

Huawei says Japan 'Extremely Important' After 50\% Rise in Procurement, Nikkei Asia Review, 27 August, 2020, available at: https://asia.nikkei.com/Spotlight/Huawei-crackdown/Huawei-says-Japanextremely-important-after-50-rise-in-procurement, accessed on 8 February, 2021.

Japan GDP Annual Growth Rate, Trading Economics, available at: https://tradingeconomics.com/japan/gdp-growth-annual, accessed on 15 January, 2021.

Japan Looks to AI as Coronavirus Challenges Quality Control Mantra, Japan Times, 5 September, 2020, available at: https://www.japantimes.co.jp/news/2020/09/05/national/science-health/artificialintelligence-coronavirus/, accessed on 11 January, 2021.

Japan's Economy Shrinks $4.8 \%$ in 2020 due to Covid, BBC News, 15 February, 2021, available at: https://www.bbc.com/news/business-

56066065\#: :text=Japan's\%20economy\%20surged\%20in\%20the,the\%20same\%20period\%20in\%20201 9, accessed on 18 February, 2021.

Japan's exports grow at faster pace in January on China demand, Japan Times, 17 February, 2021, available at: https://www.japantimes.co.jp/news/2021/02/17/business/japans-exports-grow/, accessed on 18 February, 2021. 
Japan's Service Sector Slump Deepens as COVID-19 Emergency Hits Businesses, Reuters, 3 February, 2021, available at: https://www.reuters.com/article/us-japan-economy-pmi-idUSKBN2A3021, accessed on 5 February, 2021.

Kazuhiro Noguchi, AirAsia Japan Files for Bankruptcy, Leaving 23,000 Flyers Without Refunds, Nikkei Asia Review, 18 November, 2020, available at: https://asia.nikkei.com/Business/Transportation/AirAsiaJapan-files-for-bankruptcy-leaving-23-000-flyers-without-refunds, accessed on 2 February, 2021.

Kentaro Iwamoto, Sea and BYD biggest winners among major Asia stocks in 2020, Nikkei Asia Review. 28 December, 2020, available at: https://asia.nikkei.com/Spotlight/Market-Spotlight/Sea-and-BYDbiggest-winners-among-major-Asia-stocks-in-2020, accessed on 1 January, 2021.

Masks No Obstacle for New NEC Facial Recognition System, Reuters, 7 January 2021, available at: https://www.reuters.com/article/us-health-coronavirus-japan-facial-recog-idUSKBN29C0JZ, accessed on 10 January, 2021.

Mckinsey \& Company, Mckinsey Report, available at https://www.mckinsey.com/featuredinsights/future-of-work/what-800-executives-envision-for-the-

postpandemicworkforce\#: :text=As\%20nonessential\%20workers\%20shifted\%20to,such\%20as\%20vide oconferencing\%20and\%20filesharing, accessed on 1 January, 2021.

Pandemic Threatens Global Airline Industry with Financial Losses, VOA News, 24 November, 2020., available at: https://www.voanews.com/economy-business/pandemic-threatens-global-airline-industryfinancial-losses, accessed on 1 January, 2021.

Pandemic-induced Business Failures in Japan Reach 1,000, Japan Times, 2 February, 2021, available at: https://www.japantimes.co.jp/news/2021/02/02/business/economy-business/1000-business-failurescoronavirus/, accessed on 2 February, 2021.

Philip Van Doorn, These are the Best Performing Nasdaq and S\&P 500 Stocks of 2020, Martket Watch, 2 January, 2021, available at: https://www.marketwatch.com/story/these-are-the-best-performingnasdaq-and-sp-500-stocks-of-2020-2020-12-29, accessed on 5 January, 2021.

Statista, available at: https://www.statista.com/statistics/263393/global-pc-shipments-since-1st-quarter2009-by-vendor/, accessed on 10 January, 2021.

Todd Schneider, Gee Hee Hong, and Anh Van Le, "Land of the Rising Robots," Finance \& Development, Vol. 55, no. 2, , June, 2018, available at: https://www.imf.org/external/pubs/ft/fandd/2018/06/japan-labor-force-artificial-intelligence-androbots/schneider.htm, accessed on 8 January, 2021.

Touchless Sensor Technology Takes Off in Japan, AV Magazine, 15 April, 2020, available at: https://www.avinteractive.com/news/covid-19/touchless-sensor-technology-takes-off-in-japan-15-042020/, accessed on 4 January, 2021. 
Winners and Losers in Japan's 2020 stock market, The Star, 30 December, 2020, available at: https://www.thestar.com.my/business/business-news/2020/12/31/winners-and-losers-in-japans-2020stock-market. accessed on 5 January, 2021.

World Robotics Statistics, International Federation of Robotics (IFR), available at: https://ifr.org/ifrpress-releases/news/robot-race-the-worlds-top-10-automated-co.untries, accessed on 2 February, 2021.

Yahoo Finance, available at: https://finance.yahoo.com/, accessed on 19 February, 2021. 